\title{
WORKING MEMORY IN CHILDREN WITH PHONETIC DEVIATION AND PHONOLOGICAL DEVIATION
}

\author{
MEMÓRIA DE TRABALHO EM CRIANÇAS COM DESVIO FONÉTICO E DESVIO \\ FONOLÓGICO
}

\section{Raphaela Barroso GUEDES-GRANZOTTI ${ }^{1}$; Ana Carolina Carvalho FELIPPINI ${ }^{2}$; Patrícia Aparecida ZUANETTI ${ }^{3}$; Kelly SILVA ${ }^{1}$; Danielle Ramos DOMENIS ${ }^{1}$; Patrícia Pupin MANDRA ${ }^{4}$; Marisa Tomoe Hebiara FUKUDA ${ }^{4}$}

1. Professor, Departamento de Fonoaudiologia da Universidade Federal de Sergipe - UFS, Lagarto, SE, Brasil; 2. Fonoaudióloga Clínica, Ribeirão Preto, SP, Brasil; 3. Fonoaudióloga, Hospital das Clínicas da Faculdade de Medicina de Ribeirão Preto, Ribeirão Preto/SP, Brasil. 4. Professor, Faculdade de Medicina de Ribeirão Preto da Universidade de São Paulo - USP, Ribeirão Preto, SP, Brasil.

\begin{abstract}
Phonological Deviation and Phonetic Deviation in Working Memory - Phonological loop skills regarding the comparison group. 81 children participated, between five and six years old, of both sexes, attending the first year of primary education in municipal schools. They were divided into three groups, G1 - children with Phonological Deviation; G2 - children with Phonetic Deviation and G3 - children without speech or language disorders (comparative group). The Working Memory - Phonological loop was evaluated by the Repeatition of Words Without Meaning test. Kruskal-Wallis and Dunn's Statistical Tests were used, adopting $\mathrm{p}<0.05$ as significant. The G3 group showed superior performance in the syllabic categories of two, three and four syllables when compared to G1 and G2. When comparing G1 and G2, it was observed a superior performance of G2. In all groups, it was showed a decrease of right answers when increasing the length of words. The deficits in Working Memory - Phonological loop ability were observed in children with both Phonological Deviation and Phonetic Deviation, but children with Phonological Deviation presented significantly lower performance. The results suggest the relation of the Working Memory - Phonological loop with the development of speech and language.
\end{abstract}

KEY WORDS: Memory. Language Development Disorders. Speech Disorders

\section{INTRODUCTION}

The Working Memory - Phonological loop (WMP) is a subcomponent of the working memory model proposed by Baddeley (2003). This component, in particular, is responsible for processing the verbal material and is constituted by the phonological storer or phonological loop, responsible for retaining verbal information and, by the articulatory loop, responsible for subvocal reverberation, that is, for maintaining information for a greater period before decayning (LARSEN; BADDELEY, 2003; CAMOS; BARROUILLET, 2014; REPOVS; BADDELEY, 2013). The WMP storage capacity is influenced by the length of the material to be memorized, the frequency of occurrence, the semantics similarity (BADDELEY, 2003), age and education (CUNHA; CAPELLINI, 2009; RODRIGUES; BEFI-LOPES, 2009).

For evaluating the WMP, digit repeating, repetition of words and words without meaning (non-words/pseudowords) tests are used (BADDELEY, 2003). According to Gathercole (1995), repeating pseudowords or non-words evaluates more accurately the phonological storer, since the storage of these do not present lexical, semantics and syntax influence.

The WMP plays a crucial role in various cognitive abilities, such as learning, reasoning and language comprehension. In this sense, failures in the system can cause damage in the development of speech and oral language, in lexical acquisition, in the process of learning, reading and understanding a text and in resolving mathematic problems (MAJERUS; VRANCKEN; VAN DER LIDEN, 2003; LINASSI; KESKE-SOARES; MOTA, 2005; BISHOP; ADAMS; NORBURY, 2006; GINDRI, KESKE-SOARES; $\quad$ MOTA, 2007; GIANGIACOMO; NAVAS, 2008; NEVO; BREZNITZ, 2013; GUEDES-GRANZOTTI et al., 2013; CARDOSO; SILVA; PEREIRA, 2013; TORRINGTON EATON; RATNER, 2016).

Changes related to the production of phonemes are commonly found in children and can be defined as phonetic, phonological and phonetic/phonological deviation. The phonological deviation is characterized by inadequate use of phonological rules of the language, due to a linguistic disorganization, while the phonetic deviation is a mechanical change in articulatory production arising from a motor disability involved 
in sound production or structural changes of the stomatognathic system (GLAING; ESPELAND, 2005; SMITH et al, 2005). The phonetic/phonological deviation occurs when the child presents motor skill and inappropriate use of language rules.

Some studies demonstrated the relation between WMP and the phonological aspect, stating that children with difficulties in the organization of phonological rules present deficit ability in WMP, but there are no studies that investigate the WMP ability in children with phonetic changes only (BEFI-LOPES; TANIKAWA; CÁCERES, 2012; RODRIGUES; BEFI-LOPES, 2013; VIEIRA, 2014).

Based on the above and in the few studies available that emphasize the relationship between speech disorders, mainly phonetic deviations and the WMP, added to the importance of understanding a little more of these changes, the objective of this study was to verify the performance of children with Phonological and Phonetic deviation in Working Memory - Phonological loop skills regarding the comparison group.

\section{MATERIAL AND METHODS}

This is a quantitative, analytical and crosssectional research, approved by the Ethics Committee of the institution of origin under the protocol number of 5607/2008.

The inclusion criteria were: the participants had to be children, of both sexes, aged between five and six years old, in the first year of elementary education of public schools (their guardians had to sign the Free and Clarified Consent Term). The study excluded subjects who presented alteration of semantic, syntactic or pragmatic language aspects, hearing deficiency, psychological, psychiatric or neurological disorders.

To achieve the exclusion criteria, all children underwent hearing screening performed with pure tones at frequencies of $500 \mathrm{~Hz}, 1 \mathrm{kHz}, 2$ $\mathrm{kHz}, 4 \mathrm{kHz}$, with reference intensity of $20 \mathrm{dBNA}$, using the Pediatric Audiometer, Interacoustics PA2 keeping an approximately distance of $50 \mathrm{~cm}$ of the child's ear. The evaluation of the semantic, syntactic and pragmatic language aspects was carried out through playful activities, observing both the emission and reception of the child, for forty minutes, as described in the literature (ACOSTA et al., 2003).

A total of 81 children were selected for the sample and they were subjected to the evaluations below for Speech, Language and Hearing Sciences diagnosis and composition of the three study groups:

1. Phonological Evaluation, held by the Phonological Assessment of the Children instrument (YAVAS et al, 1991). The analysis was based on the contrastive model, analysis of phonological processes and phonetic inventory. Were used to record the data: a Panasonic Digital Voice Recorder RR-US570 and a Sony digital camcorder - DCR-SR42 model.

2. Myofunctional and Craniofacial Evaluation. The children were asked to remain seated, with their feet flat on the floor, head in the usual position and facing the researcher for anthroposcopy analysis of the stomatognathic system structures (face, cheeks, lips, tongue, hard palate); mobility (lips, tongue, cheeks, jaw) and functions (chewing, swallowing, breathing).

Thus, the G1 $(n=30)$ consisted in children diagnosed with Phonological Deviation without apparent cause. G2 $(n=21)$ was consisted by children diagnosed with Phonetic Deviation, which the phonetic / phonological inventory was full, considering their age, but the sound production presented distortion or obvious phonic imprecision, justified by craniofacial or myofunctional alterations. The G3 $(n=30)$ consisted of children who did not present changes in phonetic, phonological, myofunctional and craniofacial aspects.

Later, all the children were subjected to the evaluation of Phonological Working Memory, using, as an instrument, the Repetition of Words Without Meaning test (KESSLER, 1997) composed by 30 non-words, organized into six lists or categories according to the number of syllables, each one with five words consisted of consonantvowel and consonant-vowel-consonant structures. Before the test application, all instructions were provided to the participants.

All the items of the six lists were presented separately and the child was asked to repeat immediately, after hearing each non-word said. For the groups G2 and G3, the answers were considered incorrect, when the child omitted or replaced phonemes, or when he / she could not reproduce the item presented by the examiner. For the G1, it was considered correct when the child correctly repeated the displayed item or when he / she repeated the non-word, performing phonemic exchange that was presented in the phonological evaluation. Each correct answer amounted to one point, being the maximum score for each category of syllable, five points. When the answer was incorrect, the score was not attributed. The evaluation was conducted 
with each child, individually, in a quiet room, audiovisually recorded and later transcribed for analysis.

The results were analyzed by the nonparametric Kruskal-Wallis test for intergroup comparison and the Dunn's test for multiple comparisons (post-test). It was adopted as significant value $\alpha=0.05$.

The group G1 was composed of 17 male and 13 female, G2 by 21, 15 male children male and six female children and G3, or Comparative Group, was composed by 16 males and 14 females. The subjects were not matched for age or sex.

In assessing the Phonological Working Memory, no child could perform the repetition in
GUEDES-GRANZOTTI, R. B. et al

the five and six syllables categories, performing only the repetition of the non-words with up to four syllables.

\section{RESULTS}

There was a significant difference $(\mathrm{p}<0.05)$ between the three groups regarding the average obtained in each of the syllabic categories, since as the number of syllables increased, there was a reduction in the number of correct answers among children of all groups (Figure 1).

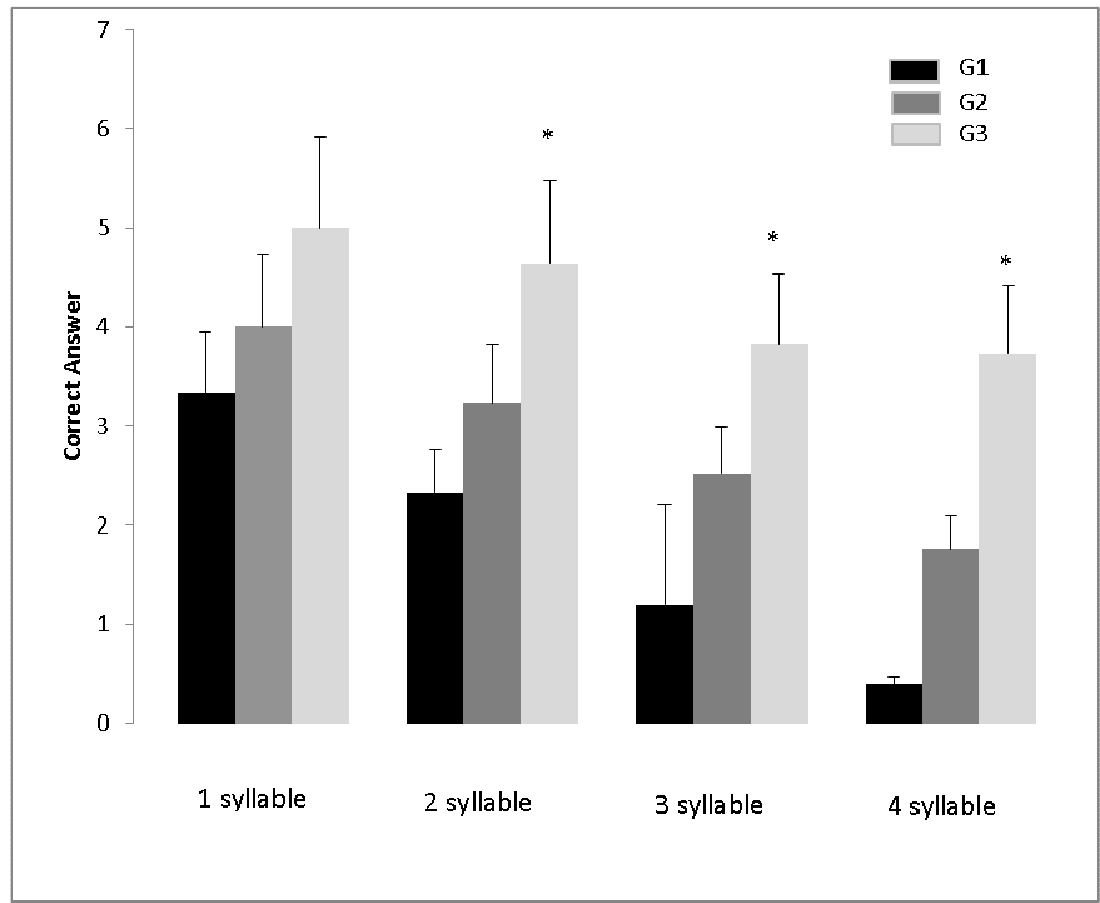

Figure 1. Average score and standard deviation in the Repetition of non-word test obtained in each group according to the syllabic category.

Subtitle: *significant values $(\mathrm{P}<0,01)$ - Kruskal-Wallis Test e Dunn's Test.: G1- children diagnosed with Phonological Deviation, G2children diagnosed with Phonetic Deviation and G3- Control Group.

Regarding the comparison between the groups, G3 showed significantly superior performance in the syllabic categories of two, three and four syllables when compared to G1 and G2 (p $<0.001$ ). Similarly, when compared G1 and G2, it was observed a significantly superior performance of G2 (p <0.001) (Figure 1).

\section{DISCUSSION}

The increasing age, associated with the literacy process causes the children to expand their knowledge about the syllabic structure and the possible combinations of sounds of language. This prior knowledge facilitates memorization and, hence, repetition of non-words allowing an increase in the WMP storage capacity during childhood (MUNSON; EDWARDS; BECKMAN, 2005; GINDRI; KESKE-SOARES; MOTA, 2007; GRIVOL; HAGE, 2012).

In this study, it can be noted that in categories of five and six syllables, none of the 81 evaluated children was successful in the repetition of non-words, showing the influence of age on the WMP (progressive increase of the memory capacity up to adolescence and decline of this ability in the third age) (GINDRI; KESKE-SOARES; MOTA, 2007; CUNHA; CAPELLINI, 2009; RODRIGUES; BEFI-LOPES, 2009). The age effect is positively related, in the case of children, to the maturational 
process processing speed (BARBOZA; GARCIA; GALERA, 2015).

Regarding the averages of correct repetition of non-words, it was observed that in all the three groups, it decreased as the number of syllables increased, demonstrating the influence of the extension. Similar results were also found in other studies that have observed better performance in the repetition of words sequences whose time of articulation to pronounce the phonemes, syllables, words or non-words was smaller due to their extent. This occurs, because the items are pronounced faster and are less likely in decaying the working memory, facilitating the process of reverberation (KESSLER, 1997; MUNSON; EDWARDS; BECKMAN, 2005; GINDRI; KESKE-SOARES; MOTA, 2007). Therefore, this variable is related to the articulatory storage.

In intergroup comparison, the results showed that the WMP skill in all syllabic categories, except monosyllables, is significantly higher in G3 children, that is, in children with proper development of speech and language. As described in other studies, a good development of WMP is important for the development of speech and oral language (LINASSI; KESKE-SOARES; MOTA, 2005; GRAY, 2006; VIEIRA, 2014) suggest that children with speech errors may have less mature working memory than peers who have mastered phonological targets earlier in development (TORRINGTON EATON; RATNER, 2016).

Comparing the groups with Phonological Deviation (G1) and Phonetic Deviation (G2), it was observed significantly underperformed skills in the WMP in children with Phonological Deviation. This can be explained, because this is a language disorder that affects phonological processing of speech, hindering the analysis of the word articulated into its constituent parts, syllables and sounds, negatively influencing both the production of speech (SMITH et al, 2005; MUNSON; EDWARDS; BECKMAN, 2005) and the retention of this phonemic sequence in the WMP, and may also positively influence the severity of the phonological deviation (LINASSI; KESKE-SOARES; MOTA, 2005).

It is important to highlight that even children diagnosed with Phonetic Deviation, that is, that present no change in phonological processing also had significantly inferior performance in the WPM test, when compared with children with normal speech and language development. Demonstrating, as observed in some studies, the WMP, besides being related to phonological child development and the acquisition and fast access of phonological properties also is related to the articulatory accuracy of the individual, resulted of motor skills involved in sound production and structural integrity of the stomatognathic system (MAJERUS; VRANCKEN; VAN DER LIDEN, 2003; MULLER et al, 2003; BISHOP; ADAMS; NORBURY, 2006).

The results of this study demonstrate the importance of a broader Speech, Language and Hearing Sciences clinical assessment that takes into account the WMP skills both in patients diagnosed with Phonological Deviation and Phonetic Deviation, since this ability seems to have an important role in the development of speech and language, and thus, help in the rehabilitation, enabling better therapeutic outcome.

\section{CONCLUSION}

Deficits in Working Memory - Phonological loop ability were observed in children with both Phonological and Phonetic Deviation, but children with Phonological Deviation presented significantly lower performance. The results suggest the relationship of Working Memory - Phonological loop with the development of speech and language.

RESUMO: verificar o desempenho de crianças com Desvio Fonológico e com Desvio Fonético nas habilidades de Memória de Trabalho - alça Fonológica com relação ao grupo comparativo. Métodos: participaram 81 crianças, entre cinco e seis anos, de ambos os sexos, que frequentavam o primeiro ano do ensino fundamental na rede municipal de ensino. Foram divididas em três grupos, G1- crianças com Desvio Fonológico; G2- crianças com Desvio Fonético e G3crianças sem alterações de fala ou linguagem (grupo comparativo). A Memória de Trabalho - alça Fonológica foi avaliada por meio da prova de Repetição de Palavras Sem Significado. Foram utilizados os testes estatísticos Kruskal-Wallis e Dunn's Test, adotando-se como significante $\mathrm{p}<0,05$. Resultados: o grupo G3 apresentou desempenho superior nas categorias silábicas de duas, três e quatro sílabas quando comparado aos grupos G1 e G2. Ao se comparar G1 e G2 observou-se desempenho superior do G2. Em todos os grupos evidenciou-se uma diminuição dos acertos com o aumento da extensão das palavras. Conclusão: os déficits na habilidade de Memória de Trabalho - alça Fonológica foram observados nas crianças tanto com Desvio Fonológico quanto Fonético, porém as crianças com Desvio Fonológico obtiveram desempenho significativamente inferior. Os resultados sugerem a relação da Memória de Trabalho - alça Fonológica com o desenvolvimento da fala e da linguagem. 
PALAVRAS-CHAVE: Memória. Transtornos do Desenvolvimento da Linguagem. Distúrbios da Fala

\section{REFERENCES}

ACOSTA, V. M.; MORENO A.; RAMOS V.; QUINTANA A.; ESPINO, O. Avaliação da Linguagem. $1^{\text {a }}$ edição. São Paulo: Editora Santos; 2003. 214p.

BADDELEY, A. Working memory and language: an overview. J Commun Disord., Amsterdam, v. 36, n. 2, p. 89-208, 2003.

BARBOZA, F. B. R.; GARCIA, R. B.; GALERA C. A. Memória de trabalho fonológica, atenção visual e leitura em crianças de $5^{\mathrm{a}}$ e $6^{\mathrm{a}}$ séries do ensino fundamental. Estud Psicol., Natal, v. 20, n. 2, p. 82-91, 2015.

BEFI-LOPES, D. M.; TANIKAWA, C. R.; CÁCERES, A. M. Relationship between the percentage of consonant correct and phonological working memory in specific language impairment. Rev Soc Bras Fonoaudiol., São Paulo, v. 17, n. 2, p. 196-200, 2012.

BISHOP, D. V.; ADAMS, C. V.; NORBURY, C. F. Distinct genetic influences on grammar and phonological short-term memory deficits: evidence from 6-year-old twins. Genes Brain Behav., Oxford, v. 5, n. 2, p. 15869, 2006.

CAMOS, V.; BARROUILLET, P. Attentional and non-attentional systems in the maintenance of verbal information in working memory: the executive and phonological loops. Front Hum Neurosci., Lausanne, v. 8 , 2014.

CARDOSO ANDREIA, M. S.; SILVA, M. M.; PEREIRA, M. M. B. Consciência fonológica e a memória de trabalho de crianças com e sem dificuldades na alfabetização. CoDAS, São Paulo, v. 25, n. 2, p. 110-4, 2013. https://doi.org/10.1590/s2317-17822013000200004

CUNHA, V. L. O.; CAPELLINI, S.A. Desempenho de escolares de $1^{\mathrm{a}}$ a $4^{\text {a }}$ série do ensino fundamental nas provas de habilidades metafonológicas e de leitura - PROHMELE. Rev. Soc. Bras. Fonoaudiol., São Paulo, v. 14, n. 1, p. 56-68, 2009.

GATHERCOLE, S. E. Is nonword repetition a test of phonological memory or long-term knowledge? It all depends on the nonwords. Mem Cognit., Austin, v. 23, n. 1, p. 83-94, 1995.

GIANGIACOMO, M. C. P. B.; NAVAS, A. L. G. P. A influência da memória operacional nas habilidades de compreensão de leitura em escolares de $4^{a}$ série. Rev. Soc. Bras. Fonoaudiol., São Paulo, v. 13, n. 1, p. 69-74, 2008.

GINDRI, G; KESKE-SOARES, M.; MOTA, H. B. Working memory, phonological awareness and spelling hypothesis. Pró-Fono Rev. At. Ci., Carapicuíba, v. 19, n. 3, p. 313-22, 2007.

GLAING, S. P.; ESPELAND, W. Low intensity phonological awareness training in a preschool classroom for children with communication impairments. J Commun Disord., Amsterdam, v. 38, n. 1, p. 65-82, 2005.

GRAY, S. The relationship between phonological memory, receptive vocabulary and fast mapping in young children with specific language impairment. J Speech Lang Hear Res., Washington, v. 49, n. 5, p. 955-69, 2006.

GRIVOL, M. A.; HAGE, S. R. V. Memória de trabalho fonológica: estudo comparativo entre diferentes faixas etárias. J Soc Bras Fonoaudiol., São Paulo, v. 23, n. 3, p. 245-51, 2011. 
GUEDES-GRANZOTTI, R. B.; FURLAN, S. A.; DOMENIS; D. R.; FUKUDA, M. T. H. Memória de trabalho fonológica e consciência fonológica em crianças com dificuldade de aprendizagem. Distúrb. Comum., São Paulo, v. 25, n. 2, p. 241-52, 2013.

KESSLER, Themis Maria. Estudo da memória operacional em pré-escolares. 1997. 36f. Dissertação (Mestrado em Distúrbios da Comunicação Humana) - Universidade Federal de Santa Maria, Santa Maria, 1997.

LARSEN, J. D.; BADDELEY, A. Disruption of verbal STM by irrelevant speech, articulatory suppression, and manual tapping: do they have a common source? Q J Exp Psychol A., England, v. 56, n. 8, p. 1249-68, 2003.

LINASSI, L. Z.; KESKE-SOARES, M.; MOTA, H. B. Habilidades de memória de trabalho e o grau de severidade do desvio fonológico. Pró-Fono Rev. At. Ci., Carapicuiba, v. 17, n. 3, p. 383-92, 2005.

MAJERUS, S.; VRANCKEN, G.; VAN DER LIDEN, M. Perception and short-term memory for verbal information in children with specific language impairment: further evidence for impaired short-term capacities. Brain Lang., v. 87, n.1, p. 160-1, 2003; https://doi.org/10.1590/s2317-17822013000200004

MUELLER, S. T.; SEYMOUR, TL; KIERAS, D. E.; MEYER, D. E. Theoretical implications of articulatory duration, phonological similarity, and phonological complexity in verbal working memory. J Exp Child Psychol Learn Mem Cogn., Washington, v. 29, n. 6, p. 1353-80, 2003.

MUNSON, B.; EDWARDS, J.; BECKMAN, M. E. Relationships between nonword repetition accuracy and other measures of linguistic development in children with phonological disorders. J Speech Lang Hear Res., Washington, v. 48, n.1, p. 61-78, 2005.

NEVO, E.; BREZNITZ, Z. The development of working memory from kindergarten to first grade in children with different decoding skills. J Exp Child Psychol Learn Mem Cogn., Washington, v. 114, p. 217-28, 2013.

REPOVS, G., BADDELEY, A. Multi-component model of working memory: explorations in experimental cognitive psychology. Neuroscience, Oxford, v. 139, n. 1, p. 5-21. 2006.

https://doi.org/10.1016/j.neuroscience.2005.12.061

RODRIGUES, A.; BEFI-LOPES, D. M. Short-term phonological memory in preschool children. CoDAS, São Paulo, v. 25, n.5, p. 422-8, 2013. https://doi.org/10.1590/s2317-17822013000500005

RODRIGUES, A.; BEFI-LOPES, D. M. Memória operacional fonológica e suas relações com o desenvolvimento da linguagem infantil. Pró-Fono Rev. At. Ci., São Paulo, v. 21, n.1, p.63-8, 2009.

SMITH, S.D.; BRUCE, F. P.; BROADA, R.; SHRIBERG, L. Linkege of speech sound disorder to reading disability loci. J Child Psychol and Psychiatry., Oxford, v. 46, n. 10, p.1057-66, 2005.

TORRINGTON EATON, C.; RATNER, N. B. An exploration of the role of executive functions in preschoolers' phonological development. Clin Linguist Phon., London, v. 30; n. 9, p. 679-95, 2016.

VIEIRA, M. G. Memória de trabalho e consciência fonológica no Desvio fonológico. Letrônica, Porto Alegre, v. 7, n. 2, p. 652-77, 2014. https://doi.org/10.15448/1984-4301.2014.2.17672

YAVAS, M.; HERNANDORENA, C. L. M.; LAMPRECHT, R. R. Avaliação fonológica da criança: reeducação e terapia. Porto Alegre: Artes Médicas; 1991. 